\title{
STATUS GIZI DAN PERKEMBANGAN ANAK USIA TODDLER (1-3 TAHUN) DI KELURAHAN KAPASARI KECAMATAN GENTENG SURABAYA
}

\author{
RUKMINI \\ AKADEMI KEPERAWATAN ADI HUSADA SURABAYA \\ ifaariqnaura@gmail.com
}

\begin{abstract}
ABSTRAK
Usia toddler (1-3 tahun) merupakan masa keemasan yang menentukan perkembangan maupun status gizi pada anak di kemudian hari. Apabila terdapat gangguan pemenuhan gizi akan berdampak pada perkembangan anak tahapan usia selanjutnya. Tujuan dilakukan penelitian ini adalah untuk menganalisis hubungan status gizi dengan perkembangan anak usia toddler (1-3 tahun) di Wilayah Kalianyar Wetan, Kapasari, Genteng, Surabaya. Jenis Penelitian ini adalah penelitian analitik. Sampel penelitian ini adalah 30 responden dengan menggunakan consecutive sampling di wilayah Wilayah Kalianyar Wetan RT 12 RW 02, Kapasari, Genteng, Surabaya. Pengumpulan data variabel perkembangan melalui lembar Denver Development Screening Test (DDST) sedangkan untuk menilai variabel status gizi dengan menggunakan kuesioner. Berdasarkan hasil uji statistik Spearman Rho menunjukkan $\mathrm{p}=0.00(\alpha<0.05)$ dan $\mathrm{r}=0.631$ sehingga terdapat hubungan yang bersifat kuat antara status gizi dengan perkembangan anak usia toddler. Apabila status gizi seimbang tidak terpenuhi maka muncullah gangguan pada perkembangan anak terutama pada pencapaian perkembangan motorik anak. Posyandu melalui kader-kadernya dapat meningkatkan kembali pelayanan kesehatan dan berperan aktif dalam mengikut sertakan warga untuk berpartisipasi berkunjung ke posyandu.
\end{abstract}

Kata kunci: status gizi, perkembangan, anak usia toddler

\section{ABSTRACT}

Toddler age (1-3 years) is a golden age that will determine the development and nutritional status of children in the future. If there is interference with nutrition will have an impact on children's development in later age. The purpose of this study was to analyze the relationship between nutritional status and the development of toddler (1-3 years) in Region Kalianyar Wetan, Kapasari, tiles, Surabaya. This research is a type of analytic. The sample was 30 respondents using consecutive sampling in the region Kalianyar Wetan RT 12 RW 02, Kapasari, tiles, Surabaya. The development data collected with Denver Development Screening Test (DDST) and for assessing the nutritional status variable used a questionnaire. Based on the results of Spearman Rho test showed $p=0.00(\alpha<0,05)$ and $r=0.631$ so that there was a strong relationship between nutritional status and the development of toddler. If balanced nutrition was not achieved, so there will be a impaired of child's development especially in achieving the motor development of children. Posyandu through its cadres can improve back health services and play an active role in the to involve citizens to participate visit to Posyandu.

Keywords: nutrition, child development, toddler 


\section{PENDAHULUAN}

Fase terpenting dalam pertumbuhan dan perkembangan anak adalah ketika masa bayi dan batita, karena pada masa itulah saat yang paling vital bagi orang tua dalam membangun fondasi pertumbuhan dan perkembangan buah hati. Proses pertumbuhan dan perkembangan pada masa bayi dan batita merupakan proses yang teramat penting dalam menentukan masa depan anak baik secara fisik, mental maupun perilaku. ${ }^{1}$ Pada masa ini ditandai oleh berbagai periode penting yang mendasar disepanjang kehidupan anak selanjutnya Salah satu periode ini dicirikan "The Golden Age Periode" atau periode keemasan, yaitu masa keemasan dari pertumbuhan dan perkembangan anak. ${ }^{8}$

Perkembangan (development) adalah bertambahnya kemampuan (skill) dalam struktur dan fungsi tubuh yang lebih kompleks dalam pola yang teratur dan dapat diramalkan, sebagai hasil dari proses pematangan. Termasuk juga perkembangan emosi, intelektual dan tingkah laku sebagai hasil interaksi dengan lingkungannya. ${ }^{1}$

Perkembangan dipengaruhi oleh beberapa faktor beberapa faktor antara lain faktor he-rediter lingkungan dan internal. ${ }^{2}$ Selain itu proses perkembangan anak dapat dipengaruhi oleh bio, fisik, psikososial, yakni dalam segi biologis nya bisa melalui lingkungan tempat tinggal keluarga, keadaan gizi anak yang kurang terpenuhi, kebersihan lingkungan yang kurang terjaga, pendidikan, kesehatan dalam diri anak, dan lain-lain sedangkan kalau dalam segi psikososialnya yakni bisa pengaruh dari keluarga nya, nilai social budaya, perbedaan agama, tradisi, adat istiadat, suku bangsa, warna kulit dan lainlain. ${ }^{7}$ Perkembangan adalah periode penting dalam tumbuh kembang anak adalah masa toddler (usia 1-4 tahun) karena pada masa ini adalah masa emas pertumbuhan anak tak hanya pertumbuhan fisik tapi juga perkembangan motorik, kognitif, bahasa dan social emosionalnya. ${ }^{5}$

Problem gizi buruk pada batita masih menjadi fokus perhatian dinas kesehatan sebab pada tahun 2014 sebanyak 440 batita masih mengalami gizi buruk dengan indikator berat badan jauh di bawah normal kalau di presentasikan jumlahnya $0.601 \%$ mengalami gizi buruk namun, kondisi ini lebih baik di bandingkan tahun sebelumnya. (Depkes, 2014). Kasus gangguan tumbuh kembang anak di Surabaya cukup tinggi. Pemicunya lebih banyak faktor ekonomi dan stimulus yang ada di lingkungan, bukan kelainan otak maupun genetik.

Tujuan penelitian ini adalah menganalisis hubungan status gizi dan perkembangan batita di Kapasari Genteng Surabaya.

\section{METODE}

Penelitian ini menggunakan rancangan penelitian observasional analitik dengan pendekatan cross sectional, dilakukan Posyandu Kapasari di Jalan Kalianyar Wetan RT. 12 RW. 02, Kelurahan Kapasari, Kecamatan Genteng, Surabaya. Penelitian ini akan dilakukan selama bulan Juli 2015.

Populasi penelitian adalah semua batita di Kelurahan Kapasari Kecamatan Genteng jumlah populasi 70 responden, sedangkan sampel adalah ibu yang mempunyai anak batita yang bersedia untuk diteliti yang datang ke Posyandu di Jalan Kalianyar Wetan RT. 12 RW. 02, Kelurahan Kapasari, Kecamatan Genteng, Surabaya yaitu 30 responden. Tehnik sampling yang digunakan dalam penelitian ini adalah consecutive sampling.

Uji statistik menggunakan Spearman Correlation Test pada perangkat lunak komputer.

\section{HASIL}

\section{Data Umum}

Tabel 1. Karakteristik Responden

\begin{tabular}{clcc}
\hline No & \multicolumn{1}{c}{ Karakteristik } & n & \% \\
\hline 1 & Pekerjaan orang tua & & \\
\cline { 2 - 4 } & Wiraswasta & 10 & 33.3 \\
\cline { 2 - 4 } & Swasta & 10 & 33.3 \\
\cline { 2 - 4 } & PNS & 5 & 16.6 \\
\cline { 2 - 4 } & Tidak Bekerja & 5 & 16.6 \\
\hline 2 & Pendidikan terakhir orang tua & \\
\cline { 2 - 4 } & SMA & 10 & 33.3 \\
\cline { 2 - 4 } & SMP & 10 & 33.3 \\
\cline { 2 - 4 } & SD & 10 & 33.3 \\
\hline 3 & Penghasilan orang tua per bulan & \\
\cline { 2 - 4 } & $500.000-1.000 .000$ & 5 & 16.6 \\
\cline { 2 - 4 } & $1.500 .000-2.000 .000$ & 11 & 36.3 \\
\cline { 2 - 4 } & $2.500 .000-3.000 .000$ & 9 & 30 \\
\cline { 2 - 4 } & $>3.000 .000$ & 5 & 16.6 \\
\hline
\end{tabular}

Tabel 1 menunjukkan karakteristik responden dilihat dari pekerjaan, pendidikan terakhir dan penghasilan orang tua per bulan. Sebagian besar pekerjaan orang tua adalah wiraswasta yaitu 10 responden $(33,3 \%)$ dan swasta yaitu 10 responden $(33,3 \%)$. 
Pendidikan terakhir orang tua sama rata yaitu SMA, SMP dan SD masing-masing 10 responden (33\%). Hampir sebagian pendapatan orang tua per bulan Rp. 1.500.000-Rp.2.000.000 yaitu 11 responden $(36.3 \%)$

Tabel 2 Karakteristik berat dan tinggi badan batita.

\begin{tabular}{clll}
\hline No & Karakteristik & $\mathrm{n}$ & $\%$ \\
\hline \multirow{2}{*}{1} & Berat Badan $(\mathrm{kg})$ & & \\
\cline { 2 - 4 } & $4.6-8.9$ & 12 & $40 \%$ \\
\cline { 2 - 4 } & $9-13.6$ & 18 & $60 \%$ \\
\hline 2 & Tinggi Badan $(\mathrm{cm})$ & & \\
\cline { 2 - 4 } & $56-75$ & 13 & $43.3 \%$ \\
\cline { 2 - 4 } & $76-96$ & 17 & $56.6 \%$ \\
\hline
\end{tabular}

Tabel 2 menunjukkan karekteristik responden berat dan tinggi badan batita. Sebagian besar batita memiliki berat badan 9 - $13.6 \mathrm{~kg}$ yaitu 18 responden (60\%). Sebagian besar batita memiliki tinggi badan $76-96 \mathrm{~cm}$ yaitu 17 responden $(60 \%)$.

\section{Data Khusus}

Tabel 3 Tabulasi silang status gizi dan perkembangan batita di Wilayah Kalianyar Wetan RT 12 RW 02 Kelurahan Kapasari Kecamatan Genteng Surabaya

\begin{tabular}{llrrrrrr}
\hline \multirow{2}{*}{ No } & Variabel & \multicolumn{4}{c}{ Perkembangan Batita } \\
\cline { 3 - 8 } & & Normal & \multicolumn{2}{c}{$\begin{array}{c}\text { Meragu } \\
\text { kan }\end{array}$} & \multicolumn{2}{c}{$\begin{array}{c}\text { Abnor } \\
\text { mal }\end{array}$} \\
\cline { 2 - 8 } & Status Gizi & $\mathrm{n}$ & $\%$ & $\mathrm{n}$ & $\%$ & $\mathrm{n}$ & $\%$ \\
\hline 1. & Baik & 10 & 33.3 & 2 & 6.7 & 0 & 0 \\
\hline 2. & Cukup & 9 & 30 & 1 & 3.3 & 0 & 0 \\
\hline 3. & Kurang & 0 & 0 & 6 & 2 & 2 & 6.7 \\
\hline \multicolumn{7}{c}{ Uji Spearman Rho $\mathrm{p}=0.00(\alpha<0.05)$ dan $\mathrm{r}=0.631$}
\end{tabular}

Tabel 3 mayoritas responden menunjukkan batita yang memiliki status gizi baik dan pekembangan yang normal yaitu 10 responden $(33.3 \%)$. Hasil uji Spearman Rho $\mathrm{p}=0.00 \quad(\alpha<0.05) \quad$ dan $\mathrm{r}=0.631$, sehingga terdapat hubungan yang bersifat kuat antara status gizi dan perkembangan anak usia toddler (1-3 tahun) di Wilayah Kalianyar Wetan RT 12 RW 02 Kelurahan Kapasari Kecamatan Genteng Surabaya.

\section{PEMBAHASAN}

Berbagai aspek perkembangan yang dipantau adalah motorik kasar, motorik halus, kemampuan bicara dan bahasa serta sosialisasi dan kemandirian. Salah satu upaya untuk mengetahui adanya penyimpangan perkembangan bayi dan batita yaitu dengan deteksi dini penyimpangan perkembangan anak. ${ }^{1}$ Melalui deteksi dini dan mengetahui adanya masalah pada perkembangan anak, maka pemulihannya dapat dilakukan lebih awal, sehingga tumbuh kembang anak dapat berlangsung optimal. Perkembangan yang utama dan diprioritaskan pada masa di bawah usia 5 tahun karena hal tersebut sebagai dasar untuk tumbuh kembang anak yang berlangsung pada masa batita akan sangat mempengaruhi dan menentukan perkembangan anak selanjutnya. Seperti pada 3 tahun pertama merupakan periode keemasan (golden period) pertama merupakan optimalisasi proses tumbuh kembang. ${ }^{5}$ Dalam Perkembangan anak memerlukan zat gisi yang baik dalam proses mempercepat perkembangan anak. Zat-zat gizi yang dikonsumsi akan sangat berpengaruh pada status gizi anak. Perbedaan status gizi memiliki pengaruh yang sangat besar perbedaanya pada setiap perkembangan anak, apabila gizi yang diperoleh anak seimbang maka tidak akan mengganggu perkembangan anak namun apabila gizi seimbang tidak terpenuhi maka terdapat gangguan pada perkembangan anak terutama pada pencapaian perkembangan motorik anak.

Dapat diketahui bahwa hubungan status gizi batita dengan perkembangan sangat mempunyai hubungan yang sangat kuat karena jika status gizi batita kurang maka bisa jadi akan menghambat proses perkembangan pada batita tersebut.

Penulis dapat mengemukakan opini bahwa terdapat beberapa faktor yang mempengaruhi proses perkembangan anak batita. ${ }^{6}$

Faktor pertama adalah pendidikan orang tua yang sangat berpengaruh terhadap perkembangan batita terutama pada pendidikan ibu. Pendidikan ibu yang rendah beresiko untuk menghambat proses perkembangan batita karena kurangnya pengetahuan ibu tentang pengetahuan. Karena orang tua dengan latar belakang yang rendah tidak mampu menggunakan dan memahami pentingnya penggunaan fasilitas kesehatan yang dapat memberikan efek yang sangat postif dan baik untuk batita, misalnya dengan teraturnya datang ke posyandu untuk imunisasi yang bertujuan untuk meningkatkan 
kekebalan tubuh dari beberapa penyakit yang bertugas sebagai tameng untuk melindungi tubuh. Sedangkan ibu yang berpendidikan lebih tinggi lebih terbuka untuk memberikan asuhan dan informaai cara memberikan rangsangan pada batita untuk mempercepat proses perkembangan dengan baik. Pendidikan orang tua juga dapat menjadi modal untuk memberikan makanan yang bergizi seperti gizi seimbang pada batita dnegan baik. Rata-rata pendidikan orang tua pada posyandu kapasari 33,3\% dan sudah memahami cara memberikan asuhan yang baik pada anak. ${ }^{8}$

Faktor kedua adalah status ekonomi (pekerjaan dan penghasilan) orang tua. Dari hasil penelitian menunjukkan orang tua responden memiliki pekerjaan yang layak $66,6 \%$ dari total keseluruhan $100 \%$, yang paling banyak adalah wiraswasta dan swasta. Pekerjaan orang tua responden sangatlah bagus dalam mencapai perkembangan yang baik, diikuti pula dengan penghasilan orang tua responden dengan paling banyak penghasilanya lebih dari Rp. 1.000.000,00 dengan prosentase $36,3 \%$ dan orang tua yang memiliki anak yang perkembanganya abnormal $100 \%$ penghasilan orang tua hanya Rp. 500.000,00 dengan catatan tidak diasuh sendiri oleh orang tua melainkan dititipkan pada keluarga yang terdekat. Dalam hal ini maka keadaan ekonomi antara pekerjaan dan penghasilan yang diperoleh orang tua responden sangat berpengaruh terhadap perkembangan maupun status gizi anaknya. Orang tua memiliki tanggung jawab yang penuh terhadap status gizi maupun perkembangan anak seperti membiayai dan memenuhi kebutuhan kehidupan sehari-hari. .

Berdasarkan hasil uraian penelitian tersebut, maka ada anak batita usia 1-3 tahun yang mengalami hambatan perkembangan maupun kurangnya status gizi dikarenakan oleh faktor orang tua yang kurang berperan aktif memantau batita secara keseluruhan.

\section{SIMPULAN}

Hasil uji Spearman Rho $\mathrm{p}=0.00$ $(\alpha<0.05)$ dan $\mathrm{r}=0.631$, sehingga terdapat hubungan yang bersifat kuat antara status gizi dan perkembangan anak usia toddler (1-3 tahun) di Wilayah Kalianyar Wetan RT 12 RW 02 Kelurahan Kapasari Kecamatan Genteng Surabaya.

\section{SARAN}

Posyandu melalui kader-kadernya dapat meningkatkan kembali pelayanan kesehatan dan berperan aktif dalam mengikut sertakan warga untuk berpartisipasi berkunjung ke posyandu. Menambah jadwal pertemuan lebih koefisien dalam menentukan tindakan dengan menambah hari untuk kegiatan bagi PAUD. Posyandu juga sebaiknya membuat program penyuluhan tentang stimulasi perkembangan anak yang bertujuan untuk menambah wawasan dan pengetahuan bagi orang tua terhadap anaknya

\section{Daftar Pustaka}

1. Donna L.Wong, 2003. Pedoman Klinis Keperawatn Pediatri. alih bahasa Monica Ester,SKp. Jakarta : ECG.

2. Ngastiyah. 2002. Perawatan Anak Sakit. Edisi 2. EGC. Jakarta

3. Notoatmodjo, Soekidjo. 2003. Pendidikan dan Perilaku Kesehatan. Jakarta: Rineka Cipta.

4. Nursalam dan Siti Paniani. 2003. Konsep dan Penerapan Metodologi Ilmu Keperawatan, Jakarta: Salemba Medika

5. Nursalam, 2005. Asuhan Keperawatan Bayi dan Anak. Jakarta: Salemba Medika.

6. Purwadarminta. 2003. Konsep dan Peranan Ibu. Jakarta: Gunung Mulia.

7. Soetjiningsih, (2003). Tumbuh Kembang Anak. Jakarta: EGC

8. Supartini, Y. 2004. Buku Ajar Konsep Dasar Keperawatan Anak. EGC. Jakarta

9. Tanuwidjaya, Suganda. 2002. Tumbuh Kembang anak. Jakarta: Sagung Seto 